\title{
BUGARSKA POLITIČKA EMIGRACIJA U KRALJEVINI SHS
}

\begin{abstract}
APSTRAKT: U članku se razmatraju organizacija, položaj, ideologija, planovi i aktivnosti bugarske političke emigracije u Kraljevini SHS, odnos vlasti prema njoj, uloga emigracije u vladinoj politici prema Bugarskoj, kao i odnosi unutar rukovodstva emigracije. Bugarska emigracija u Kraljevini SHS je tema koja do sada u domaćoj istoriografiji nije istraživana, već je samo, veoma površno, pominjana u radovima koji se bave istraživanjem odnosa dve zemlje posle Prvog svetskog rata.
\end{abstract}

Ključne reči: Zemljoradnička emigracija, Kraljevina SHS, Bugarska, spoljna politika, oružana akcija, komunisti

Bugarska politička emigracija u Kraljevini SHS je nedovoljno istražen politički i društveno-istorijski fenomen što, mišljenja smo, nije u skladu sa ulogom koju je imala u jugoslovensko-bugarskim odnosima tokom dvadesetih godina 20. veka. ${ }^{1}$ Politiku Kraljevine SHS prema bugarskoj emigraciji u godinama zaoštrenih međusobnih odnosa dva balkanska suseda možemo posmatrati dvojako: pre svega, kao jedan od nivoa (ili „koloseka“) spoljne politike Kraljevine SHS, jer je odnos prema emigraciji oslikavao od-

${ }^{1} \mathrm{U}$ domaćoj istoriografskoj literaturi gotovo da nema pomena bugarske političke emigracije, a o ozbiljnoj analizi njene uloge da i ne govorimo. Emigraciju i njenu ulogu u odnosima Kraljevine SHS i Bugarske, u jednom pasusu, pominje Desanka Todorović u svojoj monografiji Jugoslavija i balkanske države 1918-1923 (Beograd 1976) kao i u članku Jugoslovensko-bugarski odnosi u drugoj polovini 1923. godine (Jugoslovensko-bugarski odnosi u XX veku, knj. I, 179-196, Beograd 1980). U bugarskoj istoriografiji, koliko je nama poznato, emigracijom se detaljnije bavio Ljubomir Vasilev u knjizi БЗНС по време на правителството на Александър Цанков (19231925) (София 1999), gde u preglednoj formi iznosi najvažnije činjenice iz života i aktivnosti bugarske zemljoradničke emigracije. Vezama bugarske zemljoradničke emigracije sa bugarskim komunistima, Kominternom i Moskvom bavi se i Ljudmil Spasov u delu България и СССР 19171944 (Veliko Tъrnovo 2008). Položaju i organizaciji komunističke emigracije u Kraljevini SHS posvećen je članak Zdravke Mičeve Българската револючионна емиграчия в Югослав (септември 1923 - декември 1925 г.) (Векове, 5/1973, 24-36, Софиа 1976). Osim toga, u Bugarskoj su objavljeni memoari jednog od vođa emigracije Koste Todorova Изповедта на една луда балканска глава (Софија 1994). 
nos prema zvaničnoj Bugarskoj; s druge strane, odnos prema emigraciji se može posmatrati i kao odnos prema Bugarskoj i Bugarima uopšte, kroz koji su se prelamali svi oni istorijski, politički, ideološki i kulturološki aspekti, nasleđeni ili novoformirani stavovi i gledišta prema složenom pitanju srpsko-bugarskih odnosa.

\section{Nastanak i organizacija}

Nastanak bugarske emigracije vezan je za tragične događaje i unutrašnje sukobe u Bugarskoj, od sredine 1923. do početka 1926. S druge strane, pozicioniranje glavne baze bugarske emigracije u Kraljevini SHS posledica je politike koju je jugoslovenska država vodila prema Bugarskoj posle svetskog rata i suštinskih dilema koje je sama Bugarska imala u vezi sa svojom spoljnopolitičkom orijentacijom i njenom ideološkom bazom. Posleratna zemljoradnička vlada Aleksandra Stambolijskog ${ }^{2}$ promovisala je politiku „nove Bugarske“ čiji su osnovni ciljevi bili: 1) potpuno distanciranje od ranije politike "ferdinandovske" Bugarske, koja je zemlju uvukla u dva rata sa susedima (Drugi balkanski i Prvi svetski rat) i koštala dve "nacionalne katastrofe" (1913. i 1918); 2) nova politika prema susedima, posebno prema Srbiji (Kraljevini SHS) i Srbima, koja je podrazumevala zbliženje, dobrosusedstvo i miroljubivost; 3) ublažavanje teških uslova mirovnog ugovora. $^{3}$ Sva tri cilja bila su međusobno povezana i uslovljena. Ideološka platforma ovakve politike bila je ideja o "jugoslovenstvu“ tj. južnoslovenskoj federaciji koja bi, pored već stvorene Kraljevine SHS, uključivala i Bugarsku, pa i po cenu odricanja bugarskog vladara od prestola u korist srpskog (jugoslovenskog) kralja. ${ }^{4}$ Stambolijski je za vreme svoje vlade preduzeo niz spoljnopolitičkih akcija radi realizacije postavljenih ciljeva, posebno u pogledu približavanja Kraljevini SHS. ${ }^{5} \mathrm{U}$ tom pogledu, njegova politika je

${ }^{2}$ Samostalna vlada Bugarskog zemljoradničkog narodnog saveza (BZNS) na čelu sa Aleksandrom Stambolijskim, obrazovana je oktobra 1919, a pre toga BZNS je bio član koalicionih vlada.

${ }^{3}$ Mirovni ugovor u Neiju (Nejski ugovor) potpisan je 27. septembra 1919. u istoimenom predgrađu Pariza. Glavne odredbe ugovora bile su: Bugarska je izgubila Zapadnu Trakiju i Južnu Dobrudžu i manje delove teritorije koji su pripali Kraljevini SHS (Caribrod, Bosilegrad, teritorije u strumičkom kraju i dolini Timoka); ugovor je predviđao reparacije od 2,250 miliona zlatnih franaka, klauzule o kažnjavanju ratnih krivaca, restituciju u naturi (ugalj, stoka i dr.), kao i redukciju vojske i zabranu mobilizacije. (K. Todorov, Politička istorija savremene Bugarske, Beograd 1938, 312).

${ }^{4}$ O jugoslovenskoj ideologiji A. Stambolijskog videti u: Nikola D. Petkov, Aleksandar Stambolijski. Njegova ličnost i ideje, Beograd 1930; Branislav Gligorijević, Kralj Aleksandar Karađorđević, 3. knjiga, Beograd 2002, 27-30.

${ }^{5}$ Stambolijski je u toku svoje vlade dva puta preduzimao velike spoljnopolitičke ,ekspedicije“ po evropskim i balkanskim prestonicama, radi promovisanja svoje politike i traženja podrške za nju, pre svega od strane velikih evropskih sila (od oktobra 1920. do januara 1921, kada je 
krunisana sporazumom između Bugarske i Kraljevine SHS u Nišu, marta 1923, koji je predstavljao formalizaciju prethodnih napora, pre svega bugarske vlade, da sa vladom u Beogradu nađe „zajednički jezik“" oko ključnog pitanja bezbednosti jugoslovensko-bugarske granice i sprečavanje upada makedonskih komitskih bandi sa teritorije Bugarske. ${ }^{6}$ Međutim, ovaj poslednji uspeh Stambolijskog i njegove vlade ubrzao je njegov pad. Zavera protiv njega, koja je kovana od ranih dvadesetih godina, okončana je krvavim prevratom 9. juna 1923. ${ }^{7}$ Prevrat je duboko potresao Balkan, posebno Kraljevinu SHS. U prvim reagovanjima, vlada u Beogradu je prevrat ocenila kao protivan Nejskom ugovoru i direktnu pretnju Kraljevini SHS. Konkretan povod za ovakav stav vlada je našla u pokušaju Bugarske da izvrši mobilizaciju vojske. ${ }^{8}$ Tek posle angažovanja velikih sila, strasti su se smirile. ${ }^{9}$ I pored svih uveravanja nove bugarske vlade ${ }^{10}$ da nije neprijatelj Kraljevini SHS, ova je, poučena istorijskim iskustvom, ostala krajnje nepoverljiva prema Bugarskoj.

Dva krupna i vremenski bliska događaja uzrokovala su pokret naroda prema susednim državama, najviše prema Kraljevini SHS, te nastanak bugarske političke emigracije: prvi je prevrat od 9. juna 1923, a drugi, septembarska pobuna bugarskih komunista (propali pokušaj izazivanja boljše-

posetio London, Pariz, Prag, Varšavu i novembra 1922, kada je posetio Beograd i Bukurešt). O spoljnoj politici Aleksandra Stambolijskog videti: Д. Петрова, Самостоятелното управление на БЗНС 1920-1923, София 1988, 140-172; В. Василев, Правителството на БЗНС, ВМРО и българо-югославските отношения, София 1981; В. Топалов, Посещението на Александър Стамболийски във Великобритания, Изследвания по българска история, том III - Външната политика на България (1878-1944), София 1978, 267-305; М. Петров, С. Стефанова, Александр Стамболииски и блгаро-югославското сближение (октомври 1919 - юни 1923), Военноисторически сборник, 5/1981, Софиа 1981, 3-16.

${ }^{6}$ Niški sporazum je regulisao zaštitu granice od ilegalnih prelazaka makedonskih komita i ostala pitanja bezbednosti pograničnog područja, kao i borbe protiv makedonskih bandi. U formalno-pravnom smislu, reč je o više rezolucija koje je usvojila mešovita srpsko-hrvatsko-slovenačkobugarska komisija, koja je zasedala u Nišu 1-17. marta 1923. Više o sporazumu: Ž. Avramovski, $O$ stavu jugoslovenske vlade prema devetojunskom prevratu u Bugarskoj 1923. godine, Istorija XX veka, sv. IX/1968, Beograd 1968, 143-145.

${ }^{7}$ Prevrat je bio delo Vojnog saveza, organizacije aktivnih i rezervnih oficira, formirane 1919. i nezadovoljne uslovima Nejskog ugovora, kao i režimom Stambolijskog. Vojnom savezu su se pridružile građanske opozicione stranke, predvođene organizacijom Narodna sloga (Народни сговор), a podržan je i od makedonske organizacije (VMRO), koja je bila protiv saradnje Bugarske i Kraljevine SHS. O prevratu videti: Ž. Avramovski, n. d., 146-178; Военен съюз, Деветоюнски преврат, Алманах на българските национални движения след 1878 г., София 2005, 394-395, 399-400.

${ }^{8}$ Vuk Vinaver, Jugoslavija i Francuska između dva rata, Beograd 1985, 54-55.

${ }^{9}$ Isto, 55.

${ }^{10}$ Novu vladu formirale su stranke okupljene oko političke koalicije Demokratska sloga (Demokratičeski sgovor), formirane 10. avgusta 1923. Za predsednika vlade izabran je prof. Aleksandar Cankov. Njegova vlada je trajala do početka januara 1926. 
vičke revolucije u Bugarskoj). ${ }^{11}$ Septembarska pobuna je važan događaj za istoriju bugarske emigracije u Kraljevini SHS, jer se posle nje emigracija omasovila, njene aktivnosti su postale primetnije, a struktura znatno složenija (ideološki i politički nehomogena, jer su je činili emigranti agrarci i komunisti).

Posle devetojunskog prevrata širom Bugarske je počeo surov obračun sa predstavnicima i simpatizerima oborene zemljoradničke vlade. $\mathrm{Na}$ udaru su bili svi: od Stambolijskog, preko najviđenijih ljudi režima i zemljoradničke stranke, do mase njenih pristalica. Opisujući akciju novih vlasti, poslanik Kraljevine SHS u Sofiji Milan Rakić je izrazio bojazan „da se iza prvog prevrata ne prikriva drugi prevrat koji bi imao da ukloni partije opozicionog bloka od učešća u državnim poslovima. ${ }^{e 12}$ Na više tačaka u Bugarskoj došlo je do masovnog otpora novoj vlasti. ${ }^{13}$ Sam Stambolijski je, u svom rodnom selu Slavovici, sa nekoliko hiljada pristalica više dana pružao otpor, a onda je uhvaćen i posle surovog mučenja likvidiran 14. juna 1923. godine. ${ }^{14}$ Bivši ministar zemljoradnje u vladi BZNS-a Aleksandar Obov je, takođe, organizovao pristalice i pružao otpor u severnoj Bugarskoj, u plevenskom kraju. Pošto je pobeđen, emigrirao je u Rumuniju. ${ }^{15}$ Pohapšeni su ministri svrgnute vlade do kojih je vlast mogla doći i poslanici BZNS-a, a 20 poslanika je noću izvedeno iz zatvora i ubijeno. ${ }^{16}$ U sedištu BZNS-a je izvršena premetačina i konfiskovan je stranački materijal. Iako zvanično nije zabranjena, rad stranke je praktično bio paralizovan, a borba za opstanak je počela u teškim uslovima. ${ }^{1}$

${ }^{11}$ Septembarska pobuna (počela 20-21. septembra 1923. u severozapadnim krajevima Bugarske) bila je „popravni ispit“ za bugarske komuniste koji su, čekajući ishod sukoba zemljoradničke vlade i zaverenika, propustili da iskoriste devetojunski prevrat i pokrenu revoluciju, zbog čega su bili kritikovani od strane Kominterne. Ustanak je brzo propao, ostavljajući hiljade žrtava i popaljenih kuća. Među razlozima propasti bila je slabost u rukovođenju i odsustvo podrške velikih gradova u kojima je živeo najveći deo radništva. U ovoj pobuni su, osim komunista, uzeli učešće i bugarski zemljodelci, pristalice Stambolijskog, ali samo u pojedinim oblastima zemlje. O pobuni videti: България 20. век. Алманах, София 1999, 1104-1106; Л. Спасов, България и СССР 1917-1944, Велико Търново 2008, 138-148.

${ }^{12}$ Arhiv Jugoslavije, Fond poslanstva u Bukureštu, 395-9-95, (dalje AJ, broj fonda, broj fasc., jed. opisa), telegram poslanika u Sofiji Poslanstvu u Bukureštu, pov. br. 508, 13. jun 1923.

${ }_{13}$ Л. Спасов, н. д., 138-139.

${ }^{14}$ K. Todorov, Politička istorija, 347-348. - Opisujući ,,jeziv kraj“ Stambolijskog, Stevan Pavlović zaključuje da je njegovo ubistvo predstavljalo „prvo među spektakularnim ubilačkim izrazima patološke mržnje koju su ogorčeni, radikalni pokreti s desnog krila ispoljavali prema 'izdajnicima' njihovog svetog cilja. U tome će im dostojni takmaci postati rumunski legionari i hrvatske ustaše“. (S. K. Pavlović, Istorija Balkana 1804-1945, Beograd 2004, 358)

${ }^{15}$ AJ, 395-9-95 (kao u napomeni 12); Коста Тодоров, Изповедта на една луда балканска глава, София 1994, 268.

${ }^{16}$ К. Тодоров, Изиоведта, 268.

17 Л. Василев, БЗНС по време на правителството на Александър Цанков (19231925), София 1999, 11. 
Bugarski emigranti su počeli da pristižu u Kraljevinu SHS prvih dana po prevratu. ${ }^{18}$ Emigranti su na granici prolazili strogu obaveštajnobezbednosnu kontrolu, a jugoslovenske vlasti su od njih dobijale ključne informacije o stanju u Bugarskoj. ${ }^{19}$ Zbog nedostatka prvorazredne izvorne građe, nemoguće je utvrditi njihov tačan broj, pa se može govoriti samo o okvirnim ciframa. Odmah posle devetojunskog prevrata, njihov je broj bio jako mali, oko 50 lica. ${ }^{20}$ Krajem septembra (dakle, pred kraj septembarske pobune) Politika je pisala da izbeglice neprekidno stižu u Niš sa raznih graničnih sektora i da ih je već bilo oko 700, da su većinom zemljoradnici (misli se na političku pripadnost BZNS-u, a ne na ljude koji obrađuju zemlju - I. R.) i da su smešteni u paviljonu Crvenog krsta. ${ }^{21}$ Početkom oktobra isti list je izvestio da su u Niš, do tog trenutka, stigle 552 izbeglice (među kojima su većinu činili zemljoradnici i oko 40 komunista), ali da će se taj broj povećati, ,jer izbeglice neprestano stižu. " ${ }^{\prime 22}$ Po jednom izveštaju, posle septembra se broj emigranata (zemljoradnika i komunista) u Kraljevini uvećao na preko 2.000 ljudi, ali se ubrzo smanjio posle amnestije koju je bugarska vlada dala političkim krivcima, i spao na 800 ljudi, pretežno komunista. ${ }^{23}$ Istu brojku navodi i jedan od vođa emigracije Kosta Todorov (više od 2.000 ljudi). ${ }^{24}$ Neki bugarski izvori pružaju slične podatke kao i štampa, tj. da se posle septembra broj emigranata u Kraljevini SHS popeo na više od 600 lica. ${ }^{25}$ Po drugom izvoru, do kraja septembra u Niš je pristiglo oko 1500 emigranata. ${ }^{26}$ Na osnovu strukture vojne organizacije emigranata, koju Todorov iznosi u svojim memoarima, može se zaključiti da je do kraja 1923. godine u Kraljevini SHS bilo nekoliko hiljada emigranata (oko

${ }^{18}$ Revolucija u Bugarskoj, Politika, 11. jun 1923 (donoseći vesti o prevratu Politika se, između ostalog, poziva i na izjave tek pristiglih izbeglica iz Bugarske).

${ }^{19}$ Ispitivanja emigranata se sastojalo od nekoliko precizno formulisanih pitanja koja su se odnosila na opšte stanje u Bugarskoj, o čemu je svaki emigrant davao podrobne informacije, zatim na razloge emigriranja, vojnička pitanja i stanje vojske (mobilizacija u Bugarskoj), rad VMRO-a, pripremu za napad na Kraljevinu SHS i aktivnosti političkih partija. (AJ, Fond Ministarstva unutrašnjih dela, 14-28a-76a, (dalje AJ, broj fonda, broj fasc., jed. opisa), izveštaji obaveštajnog oficira. Više izveštaja i zapisnika o saslušanjima.)

20 Л. Василев, н. д., 18. Osim u Kraljevini SHS, emigranti su nalazili utočište i u drugim susednim zemljama - Rumuniji, Grčkoj i Turskoj. Neposredno posle prevrata, broj emigranata u ovim zemljama je bio jako mali: u Rumuniji oko 20 ljudi, po nekoliko emigranata u Grčkoj i Turskoj.

${ }^{21}$ У Бугарској је мир, Политика, 30. септембар 1923.

${ }^{22}$ Избеглице из Бугарске, Политика, 10. октобар 1923.

23 AJ, Ministarstvo inostranih dela KJ - Političko odeljenje, 334-8-24, Izveštaj Riste Daskalovića o bugarskoj emigraciji kod nas, Beograd, 12. avgust 1924.

${ }^{24} \mathrm{~K}$. Тодоров, Изиоведта, 274.

25 Л. Василев, н. д., 18.

26 3. Мичева, Българската револючионна емиграчия в Югославия (септември 1923декември 1925 г.), Векове, 5/1973, София 1976, 26. 
4.000 ljudi pod oružjem, dakle bez žena, dece i staraca). ${ }^{27}$ Iz šturih izvora o broju emigranata vidi se da je najmasovnije emigriranje bilo od kraja septembra, posle propasti komunističke pobune, kada su emigranti dolazili svakodnevno, pa sve do kraja 1923. godine, mada su emigranti u manjem broju pristizali i narednih godina, tokom trajanja sukoba u Bugarskoj. Punktovi za prihvat emigranata nalazili su se u pograničnim mestima (Caribrod, Bosilegrad, Pirot), odakle su upućivani u Niš. ${ }^{28}$ Emigranti su raspoređivani u pograničnoj zoni, mada je od strane nadležnih bilo prigovora zbog ovakvog rasporeda, jer su se među emigrantima nalazili i „nepouzdani ljudi“. ${ }^{29}$

Suočena sa naglim prilivom emigranata, vlada je o njima raspravljala na sednici 6. oktobra, kao o prvoj tački dnevnog reda. Posle referisanja ministra unutrašnjih dela $M$. Vujačića, odlučeno je da se Ministarstvo unutrašnjih dela pobrine za emigrante i njihove potrebe. U Niš je otputovao načelnik Javne bezbednosti MUD-a Žika Lazić da na licu mesta izvidi stanje i organizuje smeštaj i materijalnu pomoć za emigrante, uz uslov da budu lojalni građani zemlje koja ih je primila. U tom gradu je osnovan Srpskobugarski odbor sa ciljem da što pre uposli emigrante, kako ne bi bili na teretu države i građana, i da počne prikupljanje priloga za njih širom zemlje. ${ }^{30}$

Prvaci BZNS-a u emigraciji odmah su počeli sa formiranjem emigrantske političke organizacije. Među vođama su se istakla trojica bliskih saradnika Stambolijskog: Rajko Daskalov (bivši ministar unutrašnjih dela, $\mathrm{u}$ vreme prevrata bugarski poslanik u Pragu), Aleksandar Obov (ministar zemljoradnje u poslednjoj vladi Stambolijskog) i Kosta Todorov (bugarski poslanik u Beogradu, koga je prevrat zatekao na Konferenciji u Lozani). Oni su u Pragu 22. juna 1923. formirali Inostrano predstavništvo BZNS-a (Zadgranično predstavitelstvo na BZNS). ${ }^{31}$ Izabrano je i rukovodstvo IP BZNS-a u koje su ušli: Rajko Daskalov (predsednik), Kosta Todorov, Aleksandar Obov, Stefan Simov, Petar Cokov, Ivan Kentov i Hristo Getov-Obov. Predstavništvo se najpre obratilo javnosti evropskih zemalja i različitim organizacijama (Socijalističkoj internacionali, Zelenoj internacionali, Ligi za prava čoveka i građanina), obaveštavajući ih o događajima u Bugarskoj i žalosnoj sudbini sledbenika Stambolijskog. ${ }^{32}$

${ }^{27}$ К. Тодоров, Изповедта, 275.

28 3. Мичева, н. д., 26.

${ }^{29}$ AJ, 14-28a-76a, Pokret bugarskih emigranata sa granične zone u unutrašnjost naše teritorije (izveštaj obaveštajnog oficira), pov. ob. br. 470, Pirot, 13. april 1924. октобар 1923.

${ }^{30}$ Избеглице из Бугарске, Политика, 7. октобар 1923; Избегличе из Бугарске, 10.

${ }^{31}$ Л. Василев, н. д., 18.

${ }^{32}$ Исто, 19. 
Osim propagandnih aktivnosti, predstavništvo emigracije je preduzelo korake za organizovanje emigracije na terenu. Najveća pažnja posvećena je emigraciji u Kraljevini SHS, zbog blizine bugarske granice, brojnosti emigracije i blagonaklonog stava vlasti prema njoj. Stvorena je emigrantska organizacija za tajni prelazak granice. Najpre je organizovan kanal koji je od Dragomana vodio do Caribroda, za čije će funkcionisanje biti zadužen emigrant Stančo Donev, a kasnije je otvoreno još nekoliko kanala kojima su rukovodili Boris Bumbarov, Boris Hristov, Cvetko Stanijev i drugi. ${ }^{33}$ Sve se ovo dešavalo po odobrenju vlasti Kraljevine SHS. ${ }^{34}$

Veliki udarac za zemljoradničku emigraciju predstavljalo je ubistvo Rajka Daskalova u Pragu 26. avgusta 1923. Ubica Daskalova, Jordan Ciconkov (pseudonim Atanas Nikolov), bio je egzekutor smrtne kazne na koju je Daskalova, još 3. marta 1923, osudio Makedonski komitet (VMRO). ${ }^{35}$ Ista sudbina mogla je da zadesi i ostale vođe emigracije i njihove porodice. ${ }^{36}$ Posle ubistva Daskalova, došlo je do promena u vrhu emigrantske organizacije: Aleksandar Obov dolazi na čelo IP BZNS-a, Prag postaje centar redakcije lista Zemedelsko zname (koji je pokrenut u Beču) i informacione sekcije, dok Beograd postaje donekle zaseban centar sa svojom administracijom, vojnim štabom i organizacijom kanala za prelaz granice. Centar je radio pod rukovodstvom Koste Todorova. ${ }^{37}$

Već je krajem 1923. u Kraljevini SHS bila organizovana „vojna sila“ zemljoradničke emigracije: 4 bataljona, sastavljena od po 10 četa, od kojih je svaka imala 100 ljudi - ukupno oko 4.000 ljudi. ${ }^{38}$ Ova „emigrantska vojska“, u kojoj je bilo i komunista, mada u manjini, razaslata je po mestima blizu granice, organizovana u vojna odeljenja, čiji su komandiri bili odgovorni lično Todorovu, koji je stajao na čelu tajnog Revolucionarnog komiteta. $^{39}$ Članovi komiteta su tajno prelazili u Bugarsku, ostavljajući za sobom

${ }^{33}$ Исто.

${ }^{34}$ AJ, Poslanstvo u Parizu, 388-8-21 (dalje AJ, broj fonda-broj fasc.-jed. opisa), telegram Poslanstva u Parizu MID-u, pov. br. 919, 21. septembar 1923. Poslanik prenosi molbu Todorova i Obova, koji su ga posetili da se obaveste o događajima u Bugarskoj, da se organizacija na granici poveri bivšem narodnom poslaniku Stanču Donevu.

${ }^{35}$ България 20. век, 1136; AJ, 388-8-21, prepis cirkulara Centralnog komiteta VMRO-a, br. 631,15 . novembar 1923 .

${ }^{36}$ Kosta Todorov se sutradan po ubistvu Daskalova obratio poslanstvu Kraljevine SHS u Parizu, tražeći da mu se izda novi pasoš pod drugim imenom, jer je bio ubeđen da će bugarska vlada pokušati da likvidira i njega. Takođe je tražio da se pošalje nešto novca njegovoj ženi u Bugarskoj kako bi se prebacila u Beograd, jer je bugarska vlada mogla njegovu porodicu iskoristiti kao taoce. Svim zahtevima Todorova se izašlo u susret. (AJ, 388-8-21, telegram poslanika u Parizu MID-u, pov. br. 799, 27. avgust 1923; AJ, 388-8-21, telegram poslanika u Parizu - MID-u, str. pov. br. 652,4 . septembar 1923)

\footnotetext{
37 Л. Василев, н. д., 22.

${ }^{38}$ К. Тодоров, Изиоведта, 275.

${ }^{39}$ Исто.
} 
letke i plakate u kojima obaveštavaju o postojanju svog revolucionarnog komiteta. ${ }^{40}$ Takođe, održavali su odnose sa svojim saborcima koji su ostali u Bugarskoj koristeći, osim tajnih kanala za prelaze, i bugarske studente koji su se iz evropskih gradova, za vreme letnjih raspusta, vraćali u Bugarsku. ${ }^{41}$

Saradnja zemljoradničke emigracije sa komunističkim pokretom i (posle septembarske pobune) sa komunističkom emigracijom bila je vrlo intenzivna. Datira od prvih dana emigriranja. I u ovim aktivnostima emigraciju je predstavljao Kosta Todorov. On se još 7. jula 1923. obratio diplomatskom predstavniku SSSR-a u Austriji Levickom, iskazujući spremnost za zajedničku akciju sa bugarskim komunistima, i to na Kominterninoj platformi o "jedinstvenom frontu" i stvaranju "radničko-seljačkih vlada“. ${ }^{42}$ Sovjetske vlasti su odlučile da održavaju kontakte sa zemljoradničkom emigracijom, a Todorov je pozvan u Moskvu. ${ }^{43}$ Kontakti su nastavljeni sa predstavnicima komunističke emigracije: oktobra 1923. su se, uz znanje i dozvolu vlasti Kraljevine SHS, u Lapovu tajno sastali zemljoradnički predstavnici A. Obov, K. Todorov, Hristo Getov-Obov i Stefan Canov sa poznatim komunistima, vođama septembarske pobune, Georgi Dimitrovim i Vasilom Kolarovim (koji su kratko vreme posle propasti pobune bili emigranti u Kraljevini SHS). ${ }^{44}$ Do dogovora nije došlo, a komunisti su otišli za Beč, gde su formirali Inostrani biro Bugarske komunističke partije (Zadgranični biro $B K P) .{ }^{45}$ Do sledećeg sastanka došlo je početkom novembra u Beču, između Todorova i Dimitrova, na inicijativu Todorova. ${ }^{46}$ On je izložio svoj plan o oružanoj akciji za svrgavanje režima u Bugarskoj, koju je planirao za mart 1924. Od Dimitrova je tražio da sondira u Moskvi za jedan zajam koji bi bio iskorišćen u te svrhe. ${ }^{47}$ Još jedan sastanak (početkom januara 1924. u Beču) je ostao bez rezultata jer se dve strane nisu složile oko sastava buduće vlade Bugarske (posle zajedničke pobede nad aktuelnom vladom) ${ }^{48}$ Do sporazu-

${ }^{40}$ Исто.
${ }^{41}$ Л. Василев, н. д., 20.
${ }^{42}$ Национальный вопрос на Балканах через призму мировой револючии (В документах иентральных российских архивов начала-середины 1920-х годов), Часть 1, Москва, 2000, (даље: Национальный вопрос на Балканах I), док. 43 (Письмо В. П. Милютина в Президиум ИККИ о предложении представителя земледельческой эмиграции установить союз с БКП, 21. 7. 1923), 78. и 174, напомена 2

${ }^{43}$ Исто, док. 64 (Письмо Г. В. Чичерина полпреду СССР в Чехословакии К. К. Юреневу, 5. 9. 1923), 111.

44 Л. Василев, н. д., 61.

${ }^{45}$ Г. Димитров, Съчинения, том 15 (октомври 1923 - април 1924), София 1989, 9.

${ }^{46}$ Исто, 54. (Pismo Dimitrova-Kolarovu 9. 11. 1923). Po rečima Dimitrova, Todorov je tvrdio da su mu vlasti Kraljevine SHS za oružanu akciju u Bugarskoj obećale 30.000 pušaka, 200 mitraljeza ali i 2 do 3 aviona; L. Spasov, $n$. d., 177.

${ }^{47}$ Г. Димитров, н. д., 54-55; Л. Спасов, н. д., 177.

${ }^{48}$ К. Тодоров, Изповедта, 278-279. 
ma je došlo na sastanku u Moskvi februara 1924. U kojoj formi je postignut sporazum nije do kraja razjašnjeno. ${ }^{49}$ Prema informacijama koje je imao obaveštajni oficir, Todorov je „zaključio neki protokol sa Sovjetima“, prema kome je od njih dobio pomoć od „20 miliona dinara“, uz obavezu da komunistima preda 10.000 pušaka koje su zemljoradnicima obećane od strane vlade $\mathrm{u}$ Beogradu. ${ }^{50}$ Obaveštajac konstatuje da je od prve partije predatog oružja (1000 pušaka) polovina predata komunistima (500), a „pošto smo mi prestali da dajemo oružje i $\mathrm{K}$. Todorov nije mogao da odgovori obavezi u pogledu naoružavanja komunista, i Moskva je prestala da daje novac te

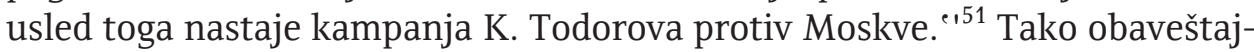
ni oficir, zadužen za praćenje rada bugarske emigracije, objašnjava preokret u politici Todorova i dela zemljoradničke emigracije koju je on predstavljao, ali i preokret u politici vlade prema emigraciji, jer je prestala da daje oružje emigrantskoj organizaciji, zato što je deo tog oružja završavao u ruke komunista.

Dve grupe emigranata su, osim na „najvišem nivou“, sarađivale i na terenu, radi regulisanja svakodnevnih životnih potreba emigranata. Tako je u Nišu formiran zajednički Emigrantski komitet, koji su činili predstavnici zemljoradnika i komunista, sa zadatkom da se stara o egzistenciji emigranata i o pravilnoj raspodeli prikupljene pomoći. ${ }^{52}$

Saradnja sa komunistima se nametala kao imperativ s obzirom na organizacione mogućnosti i podršku koju su bugarski komunisti imali od strane Sovjeta i Kominterne, kao i činjenicu da nijedna od dve velike emigrantske grupe nije imala nikakvih šansi da sama ostvari ono što je bio njihov zajednički cilj i jedino oko čega su se slagali, a to je bilo obaranje devetojunske vlade u Bugarskoj. Suštinu odnosa zemljoradničke emigracije i komunista možda je najjezgrovitije opisao visoki funkcioner Kominterne G. Zinovjev na jednoj od sednica Predsedništva IK Kominterne: „Igra se sastoji u sledećem: seljačke vođe žele da iskoriste nas, mi želimo da iskoristimo njih; razvoj događaja će pokazati ko je u tome bolji“. ${ }^{53}$

${ }^{49}$ Po Lj. Vasilevu, ne može se sa sigurnošću tvrditi da je sporazum potpisan, jer nijedan od primeraka sporazuma koji su dostupni nema potpise učesnika sastanka. On čak tvrdi da se osnovano može pretpostaviti da Todorov i Canov nisu bili saglasni sa predloženim sporazumom. (Л. Василев, н. д., 97). Za razliku od njega Lj. Spasov ističe da je sporazum potpisan 20. februara 1924. Sporazum je regulisao obaveze za obe strane u planiranom oružanom ustanku. (L. Spasov, $n$. d., 180)

${ }^{50}$ Arhiv Srbije, Lični fond Tanasija Dinića, dok. 16 (dalje: AS, TD-broj dokumenta), Referat obaveštajnog oficira Glavnog đeneralštaba pukovnika Tanasija Dinića o stanju, životu i radu bugarske emigracije kod nas, Beograd, 28. mart 1925.

${ }_{51}$ AS, TD-15, Prilog referatu obaveštajnog oficira.

${ }^{52}$ G. Dimitrov, $n$. d., 623, napomena 71; Z. Mičeva, $n$. d., 29.

${ }^{53}$ Citirano prema: Л. Спасов, н. д., 179. 
Ideologija bugarske zemljoradničke emigracije. Vođi emigracije nisu zanemarivali ideološki rad. On je bio bitan iz dva razloga: prvo, stalnim isticanjem svojih ideoloških opredeljenja uspostavljana je određena "duhovna" veza sa javnošću Kraljevine SHS, pre svega, poistovećivanjem sa pogledima na srpsko-bugarske odnose koje je ta javnost imala ali i sa kritikom „antislovenske" bugarske politike pre i posle Stambolijskog; drugo, svojim ideološkim stavom rukovodstvo emigracije je sebe, a i čitavu emigrantsku zajednicu, legitimizovalo pred vlastima Kraljevine SHS kao saveznike u zajedničkom radu na korist opšte južnoslovenske stvari.

Nekoliko je osnovnih premisa na kojima je počivala ideologija zemljoradničke emigracije (koja je bila nastavak propagiranja ideologije Stambolijskog, uz posebno isticanje "jugoslovenske" platforme te ideologije): 1) isticanje lične žrtve Stambolijskog podnete za opšti cilj južnoslovenskog (srpsko-bugarskog) pomirenja i bratstva i, s tim u vezi, javno negovanje uspomene na njega; 2) javno propagiranje ideje jugoslovenstva i slovenske solidarnosti i kritika bugarskog režima koji je izazvao rat sa Srbijom; 3) marginalizovanje makedonskog pitanja (po ugledu na Stambolijskog), skidanje istog sa liste prioriteta bugarske nacionalne politike, sve do odricanja od pretenzija na Makedoniju.

U jednom od svojih prvih proglasa u beogradskoj štampi IP BZNS je istakao da je devetojunskim prevratom „ugroženo delo slovenske solidarnosti i prijateljstvo sa bratskim narodom Srba, Hrvata i Slovenaca“, te da emigracija „ostaje verna principima koje je proklamovao njen veliki ubijeni šef." ${ }^{\text {54 }}$ Davanje parastosa Stambolijskom i ostalim žrtvama devetojunskog prevrata u Sabornoj crkvi u Beogradu, u prisustvu beogradskog građanstva, bilo je, osim religijskih i običajnih razloga, motivisano i održavanjem u srpskoj javnosti slike žrtve koju je jedan deo bugarske političke scene na čelu sa Stambolijskim podneo u ime viših ciljeva zajedničkih srpskom i bugarskom narodu. Na parastosu je Kosta Todorov održao govor o jugoslovenstvu Stambolijskog (na ovakvim skupovima, inače, nije uobičajeno da se drže politički govori), navodeći „njegovo jugoslovenstvo i njegov iskren rad na zbliženju sa Srbima" kao glavni razlog mučenja Stambolijskog, pre nego što je ubijen. ${ }^{55}$ Svoju osnovnu ideju o jugoslovenstvu i zajedničkoj budućnosti dva naroda, ideolozi emigracije su isticali i kasnije, u novinskim člancima i izjavama. ${ }^{56}$

${ }^{54}$ Проглас бугарске емиграичје, Политика, 7. јул 1923.

55 Парастос А. Стамболијском, Политика, 18. јун 1924.

56 Коста Тодоров, Бугарска и југословенско јединство, Политика, 5. септембар 1925; Југославија и Бугарска - две концепиије, Политика, 2. октобар 1925; Георги Петров, Пут југословенског јединства, Политика, 25. новембар 1925. 
Najvažnije odrednice emigrantske ideologije izneo je Kosta Todorov na velikom predavanju na Narodnom univerzitet u Beogradu krajem januara 1926 godine. ${ }^{57}$ Osnovne teze koje je Todorov izneo bile su: 1) teza o slovenskom poreklu Bugara; 2) teza o duhovnom jedinstvu Srba i Bugara; 3) teza o pogrešnoj, „antislovenskoj“, politici bugarskih vlada pre Stambolijskog; 4) teza o neophodnosti državnog ujedinjenja Srba i Bugara.

Todorov na početku predavanja ističe da je „potrebno da smo svesni da smo, uprkos svih žalosnih događaja, grane istog drveta, da smo plemena jednog naroda" i naziva bajkom tvrđenja da su Bugari Tatari, a "tatarstvo" glupom ratničkom politikom u Bugarskoj. On vidi "duhovno jedinstvo" Srba i Bugara čak i u činjenicama koje ih dele: to što se Srbi i Bugari još uvek spore da li je neki junak iz prošlosti „naš ili vaš“ ili čija je neka narodna pesma - za njega je dokaz tog jedinstva. Po pitanju srpskih i bugarskih aspiracija u Makedoniji, Todorov zastupa zvaničan srpski stav: Srbija je, pritisnuta od Austro-Ugarske, morala da traži ekspanziju na jug, prema Vardarskoj dolini, što je podržala slovenska Rusija, ali ne i slovenska Bugarska. On takođe ističe srpsku tezu da je „Makedonija (...) najvećim delom, geografski nerazdeljivo vezana sa Srbijom“, jer se dolina Vardara nastavlja na dolinu Morave. Što se srpsko-bugarskog ujedinjenja tiče, u njemu Todorov vidi jedini način da se reše sva sporna pitanja između Srba i Bugara, pre svega ono "makedonsko“, jer taj, po njemu, „besmisleni spor“ oko Makedonije, „proističe iz pretpostavke da smo dva različita naroda (....), mada je neosporna istina da smo delovi jednog naroda, čije blagostanje i progres leže u ujedinjenju." Zaključuje da Makedonija kao problem, kao i ostali nesporazumi i nepoverenje proističu iz činjenice „da smo dve države, sa dve dinastije."

Todorov, u nastavku predavanja, govori o „moralnoj nadmoći“ Srba koji su se sami izborili za svoju slobodu, dok je Bugarima ona „darovana odozgo" i veliki deo bugarskog naroda (za razliku od srpskog) nije učestvovao u osvajanju svoje slobode. „Zbog toga naša politička svest, a sa njom i politički moral, bejahu zaostali“, zaključuje. Naravno, ključna figura radikalnog zaokreta bugarske politike i ponovnog uspostavljanja pokidanih "veza“ sa slovenstvom, i posebno Srbima, jeste Stambolijski, čijom je krvlju i zavetom osvećena „zastava" ujedinjenja slovenskih, bratskih naroda.

Da svaka ideologija ima „rok trajanja“ i svoju praktičnu („upotrebnu“) vrednost, svedoči i ideologija emigracije. Todorov koji se tako žučno zalagao za ujedinjenje na bazi „dva plemena istog naroda“ (tzv. integralno jugoslovenstvo), u svojim kasnijim radovima, kada više nije bio emigrant (jer mu je početkom 1933. dozvoljeno da se vrati u Bugarsku), iznosi u

${ }^{57}$ Бугарска и Јужно Словенство, предавање г. Косте Тодорова, Политика, 23. и 24. јануар 1924. 
nekim suštinskim elementima drugačiji stav. Govoreći u svom postemigrantskom periodu o politici Stambolijskog on kaže: „Shvatio je (Stambolijski - I. R.) da u odnosima sa Jugoslavijom Bugarska ne može da stane na pola puta - da ostane na maglovitim formulama korektnog susedstva i da će se one ili zbratimiti (čuvajući svaka svoju punu državnu nezavisnost-podvukao I. R.) ili će biti večito u potajnom ratu... ${ }^{\text {58 }}$ Očigledno je da su nužnost istorijskih prilika, očuvanja "gole“ (i političke) egzistencije, snažniji imperativ od bilo kakvih političkih ili ideoloških ubeđenja, koja su podložna "fluktuiranju“ u zavisnosti od datih okolnosti.

Vlada Kraljevine SHS prema zemljoradničkoj emigraciji. Ključna tema političkog života bugarske emigracije jeste njen odnos sa vladom Kraljevine SHS. Egzistencija emigracije kao političke grupe, ali i egzistencija zajednice (svih pojedinaca ponaosob), zavisila je najviše od stava vlade u Beogradu.

Po obrazovanju svog predstavništva u Pragu, vođstvo emigracije je stupilo u vezu sa tamošnjim diplomatskim predstavnikom Kraljevine SHS Ljubom Nešićem. Preneli su mu da Kraljevinu SHS smatraju „najglavnijim poljem rada" i da upravo od nje očekuju najviše pomoći, a da je za centar određen Prag „da ne bi nama smetao (emigrantski komitet - I. R.), pošto smo mi granična država sa Bugarskom “. ${ }^{59}$ Nešiću su obećavali da će, kada ponovo budu došli na vlast, nastaviti da rade na sjedinjenju dve države. Takođe su izrazili nadu da će sa teritorije Kraljevine SHS moći da razviju široku propagandu u Bugarskoj protiv nove vlade i da će u Bugarsku slati svoje poverljive ljude radi prikupljanja podatka o stanju u zemlji. ${ }^{60} \mathrm{U}$ literaturi se može naći podatak da je jula 1923. u Pragu, između Nešića (kao predstavnika Vlade) i Daskalova, došlo do potpisivanja dokumenta o međusobnim odnosima u kome vlada Kraljevine SHS razume „zakonitu i opravdanu“ poziciju Zemljoradničkog saveza, iako ne može izbeći priznavanje nove bugarske vlade. Emigracija se obavezuje da će, pošto dođe na vlast, nastaviti politiku zbliženja i rešiti pitanje monarhije u Bugarskoj. ${ }^{61}$ Mogući takav sporazum sa predstavnicima vlade Kraljevine SHS pominje se u jednom izveštaju obaveštajnog oficira iz Caribroda, ali bez ikakvih detalja. ${ }^{62}$

Odmah po dolasku u Beograd, Kostu Todorova, koji je određen da zastupa emigraciju i njene interese pred vladom Kraljevine SHS, primili su kralj Aleksandar I i predsednik vlade Nikola Pašić. Kralj je prilikom

${ }^{58}$ Коста Тодоров, Стамболијски, Београд 1937, 120.

${ }^{59}$ AJ, 388-8-21, šif. telegram MID-a Poslanstvu u Parizu (prosleđeni izveštaj poslanika u Pragu o radu emigrantskog komiteta), str. pov. br. 402, 9. jul 1923.

${ }^{60}$ Isto.

${ }^{61}$ Р. П. Гришина, Возникование фашизма в Болгарии 1919-1925 2., София 1976, $228-229$

${ }^{62}$ AS, TD-15, Izveštaj obaveštajnog oficira, pov. ob. br. 61, Caribrod, mart 1925. 
susreta izrazio žaljenje što je delo Stambolijskog uništeno, ali i uverenje da će pre ili kasnije zemljoradnici ponovo biti na vlasti. Pašić ga je bodrio, tvrdeći mu da on poznaje dobro seljačku dušu i da je seljak spreman „da trpi dok bura ne prođe“. Zaključio je konstatacijom da su „seljaci navikli da iščekuju žetvu i žetve će biti.“63 Ova zagonetna Pašićeva parabola (po čemu je, inače, bio poznat) zapravo ništa ne govori o njegovim pravim namerama $u$ vezi sa jugoslovenskom akcijom u Bugarskoj, niti se može bez rezervi zaključiti da je on odlagao „svaku akciju do sledeće žetve“, kako se tvrdi u pojedinim radovima. ${ }^{64}$ Međutim, iz razgovora koje je Todorov vodio u Beogradu mogu se izvesti sledeći zaključci: prvo, da je vlada u Beogradu računala na zemljoradničku emigraciju kao na saveznika, s obzirom na to da je Todorov bio primljen od dvojice najmerodavnijih ličnosti Kraljevine SHS; i drugo, pokazuje se da nije bilo čvrstih i konkretnih obećanja od strane kralja i Pašića. Mogući razlozi za to su sumnja Beograda u snagu zemljoradničke emigracije (poučen devetojunskim događajima, kada su zemljoradnici vrlo brzo izgubili vlast) ili da vlada još uvek nije bila sigurna $u$ to kako treba da reaguje na dešavanja $u$ Bugarskoj. ${ }^{65}$ Međutim, najznačajnija posledica ovih susreta bila je da su čelni ljudi Kraljevine SHS de facto priznali bugarsku političku emigraciju kao političku stvarnost i saveznika u budućem razvoju događaja vezanih za stanje u Bugarskoj.

„Upotreba“ emigracije od strane Kraljevine SHS bila je višestruka. Iz obaveštajnih izvora saznajemo da je postojala ideja o tome da se zemljoradnička emigracija iskoristi kao protivteža makedonskom komitetu, „za neku eventualnu akciju za onemogućavanje akcije makedonstvujuščih. ${ }^{\text {" }}{ }^{66} \mathrm{I}$ zaista, u vreme kada se očekivao najveći upad komita (VMRO-a) u Južnu Srbiju (na proleće 1924), Ministarstvo inostranih dela je tražilo od svog Poslanstava u Parizu da se dvojica vođa emigracije Obov i Todorov, koji su se nalazili izvan Kraljevine SHS, „krajem februara ili najdalje početkom marta" vrate u Beograd ${ }^{67}$ I u Sofiji su računali na emigraciju kao na vernog saveznika vlade Kraljevine SHS koja im može zadati velike nevolje. Početkom jeseni 1923, kada su u Bugarskoj očekivali vojnu intervenciju Kraljevine SHS, predsednik vlade Aleksandar Cankov je obavestio Rakića da bugarska vlada ima izveštaje o tome da vlada u Beogradu pomaže organizovanje emigranata i da će, ukoliko oni izazovu metež u Bugarskoj, to iskoristiti kao

${ }^{63}$ К. Тодоров, Изповедта, 269-270.

${ }^{64}$ D. Todorović, Jugoslovensko-bugarski odnosi u drugoj polovini 1923. godine, Jugoslovensko-bugarski odnosi u XX veku, knj. I, Beograd 1980, 183.

${ }^{65}$ Isto, 193.

1923.

${ }^{66}$ AJ, 14-28a-76a, izveštaj obaveštajnog oficira, pov. ob. br. 220, Pirot, 18. decembar

${ }^{67}$ AJ, 388-9-22, šif. telegram iz Beograda, str. pov. br. 105, Beograd, 21. februar 1924. 
povod za vojnu intervenciju. ${ }^{68}$ Ovakvu informaciju Cankov je mogao da dobije od bugarskog poslanika u Beogradu, koji je upravo od emigranata saznao za nameru Kraljevine SHS da svojim trupama "zaplaši Cankova“ i stvori metež u Bugarskoj, posebno u vreme priprema komunističkog ustanka, kako bi pažnju Bugarske odvratila od Makedonije. ${ }^{69}$ Međutim, vojne mere koje su preduzimane bile su posledica očekivanog velikog upada makedonskih komita u prvoj polovini septembra. ${ }^{70} \mathrm{U}$ predvečerje septembarske pobune, u Bugarskoj su bili uznemireni gomilanjem trupa na granici i smatrali da je vlada Kraljevine SHS u sadejstvu sa emigrantima, od kojih je saznala da komunisti pripremaju ustanak, koji želi da iskoristi kao povod za intervenciju. ${ }^{71}$ Posebnu zabrinutost $\mathrm{u}$ bugarskim vladajućim krugovima izazvala je informacija o dolasku Todorova i Obova u Beograd. Predsednik bugarske vlade je smatrao da prisustvo emigranata blizu granice „uzbuđuje seljačke mase i može samo povećati nezgode...". Bio je vrlo zadovoljan kada mu je sa zvanične strane saopšteno da su Todorov i Obov još uvek u Pari$\mathrm{zu}^{72} \mathrm{U}$ delikatnom periodu pre, za vreme i posle septembarskih događaja, emigracija je predstavljala sredstvo dodatnog pritiska na bugarsku vladu, na raspolaganju vladi u Beogradu, koje je ona diskretno koristila, samim tim što emigranti nisu udaljavani sa granice, već je, naprotiv, tolerisana njihova organizacija i njeni kanali.

Plan zemljoradničke emigracije bio je da, koristeći teritoriju Kraljevine SHS kao bazu, izvrši oružanu akciju na teritoriji Bugarske i obori aktuelnu vladu. Objašnjavajući vesti da Bugarska gomila trupe na granici prema Kraljevini SHS u Makedoniji obaveštajni oficir Tanasije Dinić, u osnovnim crtama, iznosi Plan za revolucionarnu akciju zemljodelaca. Po tom planu, u široko zamišljenoj akciji je, pored emigranata, trebalo da učestvuju: makedonski federalisti Todora Panice; antikomitski odredi Stojana Miševa (bivšeg komite, kasnije u službi Kraljevine SHS); srpski četnici pod komandom Koste Pećanca i Ilije Trifunovića-Birčanina; „akcioni odredi“ unutar Bugarske. Napad je trebalo da bude izvršen u tri pravca: 1) prema Ćustendilu, 2) pravcem Slivnica-Sofija i 3) preko Belogračika ka Vraci. ${ }^{73}$ Major Dinić dalje

${ }^{68}$ AJ, 388-8-21, šif. telegram MID-a Poslanstvu u Parizu (prosleđeni izveštaj poslanika u Sofiji), pov. br. 671,8 . avgust 1923.

${ }^{69}$ D. Todorović, Jugoslovensko-bugarski odnosi..., 192.

${ }^{70}$ AJ, 388-8-21, šif. telegram MID-a Poslanstvu u Parizu - Predsedniku Ministarstva, 8. septembar 1923. Ministar vojni je na sednici vlade, a na osnovu izveštaja komandanta Treće armijske oblasti generala Terzića, tražio pojačanje „letećih odreda“. Napad se očekivao „oko 10. septembra".

${ }^{71}$ AJ, 388-8-21, šif. telegram MID-a - Poslanstvu u Parizu, pov. br. 9018, 20. 09. 1923.

${ }^{72}$ AJ, 388-8-21, telegram MID-a - Poslanstvu u Parizu (prosleđen izveštaj poslanika u Sofiji), pov. br. 733, 22. septembar 1923.

${ }^{73}$ AJ, 14-28a-76a, Izveštaj Komande mesta Caribrod - Komandantu Moravske divizijske oblasti, pov. ob. br. 294, Caribrod, septembar 1924. - O istim pripremama za oružanu akciju govori 
izveštava svoju komandu da se pripreme za akciju „forsirano vrše“, te da je ostalo samo da se doturi oružje unutrašnjim odredima u Bugarskoj. Međutim, iskusnom obaveštajcu nije bilo poznato odakle vesti o planovima Bugarske „da nas napadne?" Ističe da takve vesti nije dobio putem obaveštajnog rada, već od viših komandi i izražava sumnju da su te informacije "tendenciozno servirane iz redova samih zemljodelaca“. ${ }^{74}$ Navodi i pretpostavljene razloge za to: težnju emigracije da se "sa naše strane“ ubrza pomoć u oružju i novcu i da se ne propusti prilika zategnutih odnosa između Bugarske i Kraljevine SHS, koji se mogu popraviti jer su nestali oni elementi među Makedoncima koji su te odnose svakodnevno kvarili. ${ }^{75}$ Ipak, ostavlja mogućnost da bugarska vlada zaista namerava da ,jednom jačom akcijom u Makedoniji preduhitri upad revolucionara a makedonstvujušče $u$ toj akciji objedini." ${ }^{\text {"76 }}$ Predstavnici emigracije su o svojim planovima za početak "revolucionarne akcije" obavestili i predsednika vlade Nikolu Pašića, ističući kao svoj glavni cilj „svrgavanje današnjeg bugarskog tiranskog, protivnarodnog i antislovenskog režima“, očekujući svestranu pomoć vlade u Beogradu kao i to da će odluka o pomoći brzo biti usvojena. ${ }^{77}$

Osim emigranata, vojne vlasti Kraljevine SHS su, po svemu sudeći, naoružavale i tzv. akcione odrede u Bugarskoj (bugarske agrarce koji su ostali u zemlji i sa emigrantima u Kraljevini SHS pripremali oružanu akciju). Oktobra 1924, ova akcija je bila poverena ppukovniku Prvanoviću, a naređena od ministra vojnog. Posebno odeljenje od 40 ljudi bilo je formirano za prenos i održavanje komunikacije sa "prihvatnim odeljenjem“ $u$ Bugarskoj preko tajnih kanala i veza. Svi učesnici akcije su bili „zakleti“ i „svaki je ponaosob potpisao lično sebi smrtnu presudu ako bi ma šta

i izveštaj drugog agenta beogradske vlade Riste Daskalovića. On navodi da su se komunisti i zemljoradnici dogovorili o zajedničkoj akciji, ali da još nisu sigurni kada će se ona dogoditi: jedni su bili za akciju odmah (na proleće), drugi su bili za to da se sačeka septembar. Po njemu, napad je trebalo da se organizuje sa istoka i zapada, a komunisti su očekivali podršku Sovjeta, preko Varne i Burgasa. (AJ, 334-8-24, Izveštaj R. Daskalovića, 12. avgust 1924).

${ }_{74}$ AJ, 14-28a-76a, Izveštaj komande mesta Caribrod (kao u prethodnoj napomeni).

${ }^{75}$ Kada govori o nestanku „elemenata koji su svakodnevno kvarili odnose“ Kraljevine SHS i Bugarske, Dinić misli na ubistvo Todora Aleksandrova i raskol u VMRO-u posle njegovog ubistva. Ubistvo Aleksandrova je posledica sukoba unutar organizacije oko strategije saradnje VMRO-a sa Kominternom i sovjetskom vladom. Aleksandrov se oštro usprotivio pokušajima Sovjeta da izvrše „boljševizaciju“ organizacije. Ubijen je 31. avgusta 1924. Po objavljivanju ubistva došlo je do „čistki“" u VMRO-u, (tzv. „gornjodžumajski događaji“), i pobede opcije Ivana Mihajlova. Detaljnije u: Горноджумайски сьбития, Александров, Тодор, Алманах на българските национални движения след 1878. г., София 2005, 233-234, 259-260.

${ }^{76}$ AJ, 14-28a-76a, Izveštaj Komande mesta Caribrod.

${ }^{77}$ AJ, Zbirka Aleksandra Cincar-Markovića (AJ-310), fasc. 1, Deklaracija predstavnika legalne i ilegalne organizacije zemljoradničke emigracije (na bugarskom), Beograd, 18. jul 1924. Dekleraciju su potpisali: A. Obov (u ime IP BZNS), K. Todorov (u ime Tajnog revolucionarnog komiteta) i Nikola Petrini (kao predsednik Unutrašnjeg akcionog komiteta). 
odao. ${ }^{\text {"78 }}$ Kurir za vezu, koji je bio stalno nastanjen u Pirotu, bio je ujedno i putovođa. „Tovar“ je preko granice (preko masiva Stare planine) prenošen na mazgama. Po izveštaju obaveštajnog oficira, ppukovnik Prvanović je bio nemaran, pa je preko granice preveo „prazne mazge“ jer nije bio u toku („tovar" je, mimo njegovog znanja, ranije istovaren u okolini Caribroda). Prvanović je, naknadno, uspeo da prenese samo deo „tovara“, dok je obaveštajni oficir u Caribrodu nastavio sa tom akcijom. ${ }^{79}$

Deo oružja koje je vlada doturala zemljoradničkoj emigraciji završavao je u rukama komunističke emigracije čiji je centar bio u Nišu, zahvaljujući „uslugama“ izvesnog Svetozara Petrovića koji je bio upućen u sve „što se u Jugoslaviji radi između predstavništva Zemljoradničkog saveza i jugoslovenske vlade." Osim toga, Petrović je služio i kao veza između Međunarodne organizacije Crvene pomoći (MOPR), odnosno njene balkanske centrale $\mathrm{u}$ Beču i bugarske komunističke emigracije u Kraljevini SHS. ${ }^{80}$

Uloga Vojske Kraljevine SHS je naročito važna u organizovanju emigracije. Aleksandar Cankov u svojim memoarima ističe da je veoma uticajna tajna oficirska organizacija „Bela ruka“ bila „pokrovitelj“ emigracije. ${ }^{81}$ Ova organizacija je bila jako nezadovoljna načinom svrgavanja Stambolijskog i tražila je jugoslovensku intervenciju i ponovo uspostavljanje vlasti agraraca ${ }^{82}$ I kralj Aleksandar je pao pod njihov uticaj, ali je predsednik vlade Nikola Pašić „ohladio strasti“ zapretivši ostavkom. ${ }^{83}$ Ovakvu tvrdnju je teško dokumentovati, budući da o samoj organizaciji ima malo proverenih podataka i izvora, a mnogo više tajni i pretpostavki. U prilog joj ide činjenica da je komandant mesta Caribrod, obaveštajni oficir - major (kasnije

${ }^{78}$ AS, TD-9, izveštaj obaveštajnog oficira iz Caribroda o misiji ppukovnika Prvanovića, Caribrod, 10. oktobar 1924. Obaveštajni oficir u izveštaju kritikuje rad ppukovnika Prvanovića. Iako se nigde izričito ne pominje da se radi o prenosu oružja već o „tovaru“ koji je stigao u vagonima za Komandu mesta u Caribrodu, „delikatnom naređenju“ itd., jasno je o čemu je reč. Tajnovitost je razumljiva, jer se radilo o visokom stepenu konspiracije u čitavoj akciji u koju su bili uključeni i vođi emigracije (Hristo Stojanov je obaveštajnog oficira obavestio da je ministar vojni izdao naređenje ,za pomenuto“), a u tom periodu emigracija je najaktivnije radila na pripremama oružane akcije - sve to, kao i drugi navedeni obaveštajni izveštaji, nedvosmisleno ukazuje da je reč o prenosu oružja.

${ }^{79}$ Isto.

${ }^{80}$ Национальный вопрос на Балканах через призму мировой револючии (В документах иентральных российских архивов начала-середины 1920-х годов), Часть 2, Москва 2003, док. 315 (Записка Г. Генова М. А. Трилиссеру о деятельности Св. Петровича при подготовке вооруженного востания в Болгарии в 1924 г.,), 652-654. (даље: Национальный вопрос на Балканах II). O S. Petroviću se zna da je bio član Radikalne stranke, za vreme rata vojni zarobljenik u Bugarskoj kada je stupio u kontakte sa bugarskim komunistima i zemljoradnicima. Triliser, šef sovjetske spoljne obaveštajne službe, sumnjao je da je Pašićev agent.

\footnotetext{
${ }^{81}$ А. Цанков, Моето време. Мемоари, София 2002, 340.

${ }^{82}$ А. Цанков, България в бурно време. Спомени, София 1999, 207.

${ }^{83}$ Исто.
} 
ppukovnik) Tanasije Dinić, zadužen za obaveštajni rad prema Bugarskoj i bugarsku emigraciju sve do polovine 20 -ih godina, bio pripadnik "klike“ generala Petra Živkovića tj. „Bele ruke“. ${ }^{84}$

Jasno je da su emigranti koristili napete odnose između dve države da bi održali svoje pozicije u političkim planovima Beograda, osigurali svoju „važnost“ kao činioca i izazvali ako ne direktnu pomoć Kraljevine SHS, u vidu vojne intervencije, onda indirektnu, u vidu logistike i zaštite. Politička egzistencija organizacije bugarske zemljoradničke emigracije je zavisila od odnosa Bugarske i Kraljevine SHS i nikako im nije bila u interesu bilo kakva forma približavanja dve zemlje. Za razliku od komunističke emigracije, koja je iza sebe imala inostranu organizaciju BKP, Kominternu, MOPR, pa i Moskvu u poslednjoj opciji, dakle dobro međunarodno zaleđe, zemljoradnicima je opstanak zavisio od podrške, pre svega, Kraljevine SHS. Emigraciju su podržavale ne samo Pašićeve vlade, čija je spoljna politika smatrana „radikalnijom“, barem kada je reč o odnosu prema Bugarskoj, već i vlada demokrate Ljube Davidovića (od jula do novembra 1924), koja je dopustila doturanje oružja i materijala zemljoradnicima. ${ }^{85}$ Međutim, akcije emigracije su, barem kada su sovjetski obaveštajni izvori u pitanju, pre svega vezivane za planove Nikole Pašića. ${ }^{86}$ Postojanje mnoštva ovakvih informacija svedoči o tome da je i u diplomatskim i u obaveštajnim krugovima uloga zemljoradničke emigracije vezivana prevashodno za politiku Kraljevine SHS.

Pitanje emigracije u Kraljevini SHS bilo je prava „noćna mora“ za bugarski politički vrh. Bugarske vlasti su ovo pitanje pokretale i pred diplomatskim predstavnicima velikih sila u Bugarskoj. I predsednik vlade Cankov i kralj Boris su se žalili britanskom predstavniku V. Erskinu na akcije emigracije i držanje Kraljevine SHS prema njoj. ${ }^{87}$ Posebno je žestoka bila međunarodna kampanja Bugarske protiv vlade Kraljevine SHS i emigracije posle atentata koji su komunisti izveli u Crkvi Sv. Nedelje u Sofiji 16. aprila

${ }^{84}$ Саша Мишић, Албанија: противник и пријатељ, Београд 2009, 116, напомена 456.

${ }^{85}$ Национальный вопрос на Балканах II, док. 315, 652.

${ }^{86}$ Jedan od takvih izveštaja, pod nazivom Kombinacije Pašića (od 19. januara 1925), a koji se poziva na informacije dobijene u Poslanstvu Kraljevine SHS u Varšavi, kaže da je Pašićev cilj bio da uz pomoć zemljoradničkih emigranata svrgne dinastiju u Bugarskoj, kako bi istu pripojio Kraljevini SHS. (Национальный вопрос на Балканах II, 355, напомена 1). Tačnost ovakvih informacija treba uzeti sa rezervom, jer je jedan od razloga za neintervenisanje Kraljevine SHS posle devetojunskog prevrata bilo i protivljenje kralja Aleksandra, koji se plašio za sudbinu monarhije u Bugarskoj. (Uporedi: D. Todorović, Jugoslavija i balkanske države, Beograd 1979, 223-224)

${ }^{87}$ Documents on british foreign policy, first series, vol. XXVII (даље DBFB/XXVII), док. 19 (Mr. Erskine to Mr. Chamberlain, Sofia, 27.01.1925.), London 1986, 38; Цар Борис III в британската дипломатическа коресподенџия (1919-1941 г.), том I, док. 45 (Доклад от У. Ђрскин до Форин офис за проведен разговор с цар Борис, 20. 8. 1926), София 2005, 114. 
1925, kada je stradalo preko 100, a povređeno nekoliko stotina ljudi. ${ }^{88}$ Bugarski visoki zvaničnici i celokupna štampa optuživali su zvanični Beograd da stoji iza svih nevolja u Bugarskoj i to najviše štiteći emigrante. ${ }^{89}$ Bugarska diplomatija je od velikih sila tražila da utiču na Beograd da iseli emigrante iz graničnog područja. ${ }^{90}$ Čak su i Sjedinjene Američke Države, kojima Balkan nije bio u sferi primarnih interesa, zemljoradničku emigraciju smatrale preprekom dobrosusedskih odnosa. ${ }^{91}$ Vlada je na kraju morala da popusti i maja 1925. donese mere o iseljavanju bugarskih emigranata iz svih pograničnih mesta i gradova (Niša, Pirota, Caribroda i dr.), oduzimanju oružja i strogoj kontroli njihovog kretanja. ${ }^{92}$ Emigranti su iseljeni $u$ unutrašnjost zemlje - najviše u Gornji Milanovac i Požarevac, a kasnije raseljeni i po mestima u Vojvodini. ${ }^{93}$

Emigrantsko pitanje je, međutim, i dalje predstavljalo smetnju spoljnoj politici Kraljevine SHS. Delatnost emigracije je, i posle rascepa u emigraciji i propasti ideje o oružanom ustanku u Bugarskoj, bilo jedno od spornih pitanja odnosa Kraljevine SHS i Bugarske. Bugarska emigracija je predstavljala spoljnopolitički teret za Kraljevinu SHS, jer je ova, zbog izmenjenih međunarodnih okolnosti i agresivne italijanske politike na Balkanu u drugoj polovini 20-ih godina, težila zbliženju i sporazumevanju sa Bugarskom. Emigranti su, takođe, nastavili sa upadima na bugarsku teritoriju. Poslanstvo u Sofiji je insistiralo da se po ovom pitanju nešto hitno preduzme, jer su Bugari činili ozbiljne i iskrene napore da sa svoje strane spreče upade komitskih bandi. ${ }^{94}$ Drugi deo „emigrantskog tereta“ je predstavljalo nepostojanje jedinstvene državne strategije u pogledu emigracije. Zahtevi Ministarstva inostranih dela upućeni Ministarstvu unutrašnjih dela i Ministarstvu vojske i mornarice da se spreče prelasci emigranata, jer je to

${ }^{88}$ Л. Василев, н. д., 180.

${ }^{89}$ Нама влада, бугарска емиграција и Москва, Политика, 23. април 1925; Бугарска влада оптужује Србију, 24. април 1925.

${ }^{90} \mathrm{DBFB} / \mathrm{XXVII}$, dok. 127 (Mr. Chamberlain to Lord Crewe and Sir R. Graham, FO, 19. 5. 1925.), 184.

${ }^{91}$ AJ, 388-9-23, telegram MID-a - Poslanstvu u Parizu (izveštaj Poslanstva u Sofiji), pov. br. 176, 4. januar 1925 .

92 AJ, 388-9-23, telegram MID-a - Poslanstvu u Parizu, pov. br. 2601, 2. maj 1925; Интернирање бугарских емиграната, Политика, 28. април 1925. Vlada je mere nadzora nad emigrantima donela posle napada emigranata na bugarsko pogranično selo Godeč (7. februara 1925), a mere iseljenja iz Niša u G. Milanovac posle atentata u Sofiji.

${ }^{93}$ Национальный вопрос на Балканах II, док. 285 (Из отчета Эмигрантской партийной организации в Югославии о ее деятельности в 1924-1925), 588, 590-591; Л. Василев, н. д., 142.

${ }_{94}$ AJ, 334-8-28, Referat o našim odnosima sa Bugarskom i glavnim pitanjima sa ovom zemljom, 31. avgust 1927 (autor referata je službenik MID-a I. Miličić). 
suprotno državnim interesima, ostajali su bez odgovora. ${ }^{95}$ Očigledno da je svaki resor vodio „svoju politiku“ po ovom pitanju, u skladu sa svojim nadležnostima, ciljevima i zadacima.

Raskol u zemljoradničkoj emigraciji i njegove posledice. Rascep u emigraciji je bio uslovljen dubokim podelama u rukovodstvu, ličnim ambicijama i različitim pogledima na strategiju opstanka i delovanja emigracije. Sukobi između vođa emigracije počeli su još sredinom 1924. i kulminirali do jeseni iste godine (sukob Aleksandra Obova i Stefana Canova i formiranje njihovih grupa u niškom logoru), ali su pojačani posle bekstva iz zatvora i emigriranja u Kraljevinu SHS dvojice bivših funkcionera zemljoradničke vlasti - Hrista Stojanova i Nedeljka Atanasova, avgusta 1924. ${ }^{96}$ Atanasov i Stojanov su bili veoma uticajni i poštovani u zemljoradničkim krugovima, tako da su odmah uključeni u emigrantsko rukovodstvo. ${ }^{97}$ Do prvih sporenja u novom, uvećanom rukovodstvu došlo je još oktobra 1924, da bi zatim unutrašnji sukob prerastao u otvoreno rivalstvo početkom naredne godine i preneo se među emigrante $u$ drugim državama. ${ }^{98} \mathrm{Na}$ sastanku emigracije koji su u Nišu organizovali Atanasov i Stojanov sa svojim pristalicama (krajem marta 1925), Aleksandar Obov je izbačen iz rukovodstva emigracije. ${ }^{99}$ Međutim, istog dana u Niš su stigli Todorov i Obov, te je došlo do fizičkog obračuna između pristalica dve grupe, uz upotrebu vatrenog oružja. ${ }^{100}$ Ovaj događaj je ozvaničio rascep u zemljoradničkoj emigraciji i IP BZNS-a je faktički prestalo da postoji, mada su lideri obe grupe nastavili aktivnosti, organizujući niz konferencija i skupova. ${ }^{101}$ Ovakvo ponašanje emigracije (ometanje javnog reda i mira) dodatno je olakšalo odluku vlade, motivisanu najpre spoljnopolitičkim razlozima, da ih razdeli i raseli: pristalice grupe Obov-Todorov premeštene su u Požarevac, a grupe Stojanov-Atanasov u Gornji Milanovac.

Razlozi rascepa su mnogobrojni, a najvažniji su: 1) različito gledanje dveju emigrantskih grupa na saradnju sa vladama drugih zemalja $u$ toku priprema za novu oružanu akciju planiranu za proleće 1925 . godine. ${ }^{102}$

${ }^{95}$ Isto. U MID-u su smatrali da policijske vlasti šalju emigrante na bugarsku teritoriju radi prikupljanja informacija.

96 Л. Василев, н. д., 138-139.

${ }^{97}$ К. Тодоров, Изповедта, 298 - Стојанов је одређен за одржавање везе са БЗНС-ом у Бугарској, а Атанасов за исхрану и одевање емиграната. (Л. Василев, н. д., 138)

98 Л. Василев, н. д., 140.

${ }^{99}$ Исто, 141.

${ }^{100}$ Исто; Сукоб у бугарској емиграцији, Политика, 30. март 1925.

101 Л. Василев, н. д., 188-189.

${ }^{102}$ Za planiranu akciju Todorov je obezbedio podršku oko 3000 srpskih dobrovoljaca pod komandom vojvode Ilije Trifunovića-Birčanina. Birčanin mu je osigurao i 5.000 bombi, iz zaliha ,jugoslovenske Nacionalne organizacije“ (Todorov verovatno misli na Organizaciju jugoslovenskih nacionalista, ORJUNA - I. R.), koje su bile sakrivene u velikom vinskom podrumu u Nišu. Zbog 
Naime, grčka vlada je nudila pomoć u zamenu za pismeno odricanje rukovodstva emigracije od bugarskih zahteva za izlaz na Egejsko more (što je bilo pravo Bugarske po mirovnom ugovoru iz Neija): ${ }^{103}$ 2) dve grupe su optuživale jedna drugu za saradnju sa komunistima. Službenici i agenti vlade u Beogradu bili su skloni da za saradnju sa komunistima optužuju samo Obova i Todorova. ${ }^{104}$ Međutim, i Stojanov i Atanasov su bili pristalice ideje „jednog fronta" sa komunistima, još iz svojih zatvorskih dana. ${ }^{105} \mathrm{I}$ oni su, kao i Todorov, pregovarali sa G. Dimitrovim u Pragu (1-2. septembra 1924), a zatim postigli dogovor o zajedničkoj akciji. ${ }^{106} \mathrm{~S}$ druge strane, predstavnici emigracije su i jugoslovenskoj strani nudili velike ustupke, čak su išli i dalje od odricanja od aspiracija na srpski deo Makedonije. Tako su Obov i Todorov, oktobra 1925, ponudili ministru Ninčiću pismeno odricanje od bugarskog dela Makedonije (Pirinska Makedonija), što bi bilo izvršeno kada zemljodelci dođu na vlast, $\mathrm{u}$ formi ispravke granice. Isto ovo je, pre njih, vladi u Beogradu nudio i Rajko Daskalov. ${ }^{107}$

Jugoslovenska vlada je, posle rascepa, nastavila da finansira obe emigrantske grupe, pokazujući više simpatija prema grupi Obov-Todorov jer je u emigraciju bila jača u odnosu na suparničku grupu. Nastojanja vlade da pomiri dve grupe nisu urodila plodom. ${ }^{108}$

Odnosi Kraljevine SHS i Bugarske bili su ključna konstanta u delovanju bugarske emigracije i njena politička snaga i uticaj zavisili su od stanja tih odnosa. Tako je emigracija sa pojačanim aktivnostima Kraljevine SHS tokom 1927/28. godine da pronađe iskren sporazum sa Bugarskom gubila na značaju i sve više postajala ozbiljan problem jugoslovenske spoljne politike.

komunističkog atentata u Crkvi Sv. Nedelje u Sofiji i reakcije bugarske vlade do oružane akcije zemljoradničke emigracije nije došlo. (К. Тодоров, Изповедта, 306-307)

${ }^{103}$ Dve emigrantske grupe su kasnije napadale jedna drugu zbog pristanka na takav sporazum. Istina je, verovatno, da su svi pristali na tako nešto i za to dobili novac koji su kasnije međusobno podelili. (Л. Василев, н. д., 141)

${ }^{104}$ AS, TD-16, Referat obaveštajnog oficira... (kao u napomeni 50); AJ, Ministarski savet KJ, 138-21-82, Izveštaj Riste Daskalovića o bugarskoj emigraciji, Beograd, 23. april 1925.

105 Л. Василев, н. д., 60.

${ }^{106}$ Isto, 158; 3. Мичева, н. д., 35; Национальный вопрос на Балканах II, док. 89 (Из протокола № 41 заседания Президиума БКФ, 4. 9. 1924) и напомена 7, 159-162.

${ }^{107}$ Arhiv SANU, Zaostavština Milana Antića, 14387/9532, beleška sačinjena 8. oktobra 1925.

${ }^{108}$ AJ, 334-8-28, Referat o našim odnosima sa Bugarskom... (kao u napomeni 94). 
Ivan Ristić

\author{
BULGARIAN POLITICAL EMIGRATION \\ IN THE KINGDOM OF SERBS, CROATS AND SLOVENES
}

\title{
Summary
}

The topic on the article is Bulgarian political emigration in the Kingdom of Serbs, Croats and Slovenes (SHS). They were followers of Alexander Stamboliski and the Bulgarian Communist Party. Emigration was formed after a coup in Bulgaria on the $9^{\text {th }}$ June 1923 (agrarian emigrants) and a unsuccessful communist revolution on September of the same year (Communist emigrants). They become political refugees in the Kingdom of SHS, since it has been an opponent to the new Bulgarian government. The leaders of the agrarian emigration (Rayko Daskalov, Kosta Todorov, Alexander Obov) immediately formed a political organization. The organization's most important center was Belgrade runned by the Kosta Todorov. The agrarian emigrants in the Kingdom of SHS created the secret Revolutionary committee. The aim of this committee was to overthrow Bulgarian government, and therefore they have entered into an alliance with the Communists. They even received weapons and other aid from the government of the Kingdom of SHS. Later, they made several attacks on the territory of Bulgaria, operating from the territory of the Kingdom of SHS. Their organization disintegrated in the spring of the 1925 following the disputes among the agrarian emigration leaders. After the 1925, the Bulgarian emigration started to be a problem in relationship between the Kingdom of SHS and Bulgaria, and follwoing it lost its role in foreign policy of the Kingdom of SHS. 